УДК 655.326.1+655.3.062

(ㄱ П. О. Киричок, д-р техн. наук, проф., О. П. Шостачук, старш. викл., КПІ ім. Ігоря Сікорського, Київ, Україна

\title{
ДОСЛІДЖЕННЯ ВПЛИВУ \\ ТЕХНОЛОГІЧНИХ ТА ЕКСПЛУАТАЦІЙНИХ \\ ВЛАСТИВОСТЕЙ ГОФРОВАНОГО КАРТОНУ \\ НА ПРОЦЕС ДРУКУ \\ НА ФЛЕКСОГРАФІЧНИХ АРКУШЕВИХ МАШИНАХ
}

Представлено перелік технічних та експлуатаційних властивостей гофрованого картону. У дослідженні розглядаються функціональні показники першої групи, що стосуються, насамперед, вимог до жорсткості паковання. Крім того, проводиться систематизація Факторів, що впливають на функціональні характеристики та параметри друкарського апарату за типовими явищами, що відбуваються в процесі друку.

Ключові слова: флексографічний друк; друкарський апарат; гофрований картон; лайнер; флютінг; тиск.

\section{Постановка проблеми}

Актуальність аналізу і дослідження впливу експлуатаційних властивостей гофрованого картону на якість проходження процесу друку спричинені широким спектром витратних матеріалів, що використовуються та відсутністю чітких рекомендацій щодо застосування тих чи інших їх видів для паковання.

\section{Мета роботи}

Дослідити вплив технологічних і експлуатаційних властивостей гофрованого картону на процес друку на флексографічних аркушевих машинах, провести аналіз існуючих матеріалів і визначити ключові аспекти при їх застосуванні.

\section{Результати проведених досліджень}

Технологічні та технічні властивості поліграфічного обладнання, а саме флексографічних аркушевих машин, характеризуються: показниками призначення, які визначають його технологічні можливості; функціональними показниками, до яких відносимо різноманітні параметри технологічного процесу, особливості проходження та вимоги, які ставляться до кінцевої продукції [1, 2]. Для аркушевих флексографічних машин для задруковування гофрованого картону технологічні можливості розкриваються через параметри вихідної продукції [3] та властивостей витратних матеріалів. Зокрема, вони впливають не тільки на параметри

() Автор(и) 2020. Видавець КПІ ім. Ігоря Сікорського.

CC BY 4.0 (https://creativecommons.org/licenses/by/4.0/). 
технологічного процесу, але і визначають технологічну схему роботи машини та її складових частин. Завдяки проведеному аналізу було систематизовано фактори, що впливають на технологічні властивості флексографічних аркушевих машин.

Гофрований картон - багатошаровий компонентний матеріал, до складу якого входять послідовно з'єднані елементи плоского аркуша паперу (лайнера) та одно- або декількох гофрованих шарів (флютінгу). У випадку багатошарового гофрованого картону - зовнішні лайнери називають покривними (рис. 1).

Залежно від кількості гофрованих шарів розрізняють 2-о, 3-и, 5-ти, 7-ми, 9-тишаровий гофрований картон, що класифікують та розділяють за загальною кількістю гофрованих і плоских шарів:

Д - двошаровий - складається з одного плоского та одного гофрованого шарів;

Т - тришаровий - складається з двох плоских шарів, та одного гофрованого шару;

П - п'ятишаровий - складається з трьох плоских (двох зовнішніх та одного внутрішнього) та двох гофрованих шарів.

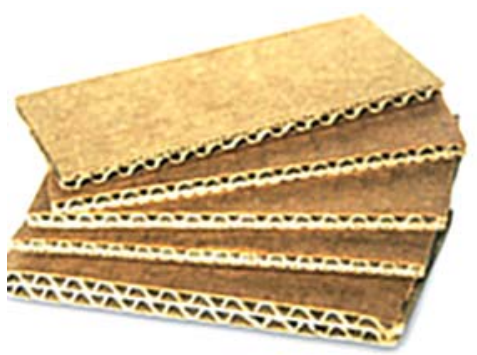

Рис. 1. Види гофрованого картону
Головними параметрами, що визначають фізико-механічні характеристики гофрованого картону є:

- крок та довжина хвилі гофру (рис. 2). Залежно від їх параметрів та значень на погонний метр може бути від 108 до 560 хвиль. В свою чергу цей параметр суттєво впливає на значення опору площинному стиску гофрованого аркуша та частково на показники гладкості його поверхні;

- міцність на стиск лайнерів (опір на стискання), які фіксують через положення гофрів, функціонують на стиснення, розрив і опір продавлюванню.

Структурно гофрований картон може мати різні типи гофрованих шарів, що обумовлює його фізико-механічні параметри [4]. Види гофрів і їх параметри систематизовані за різними типами гофрованого картону (табл. 1), що регламентуються ISO 3039-2011.

Картон для плоских шарів картон-лайнер (англ. linerboard). Складається з двох і більше елементів і шарів, що розділяються на окремі види залежно від застосованих при його виготовленні півфабрикатів та зовнішнього вигляду покривного шару $[5,6]$. Масова частка лайнерів

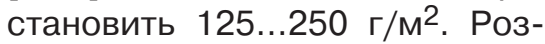
різняють наступні види:

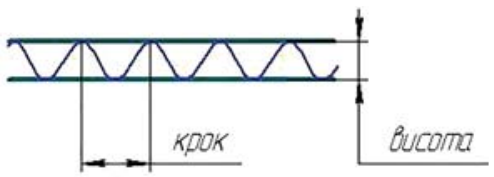

Рис. 2. Параметри гофрованого картону 
- картон-лайнер бурого кольору без покриття (англ. brown liner), картон-лайнер з білим покривним шаром (англ. white-top liner) та крейдований лайнер (англ. coated liner);

- папір для гофрування флютінг (англ. fluting) - здебільшого виготовляють одношаровим і залежно від первинної сировини розділяють на півцелюлозний (англ. cemichemical) і макулатурний (recycled). Флютінг має масову частку від 110 до 150 г/м², але якщо паковання призначене для використання в екстремальних умовах або транспортування чи зберігання товару, що легко може бути пошкоджене, то даний показник повинен становити не менше 175, 200 та 225 г/м²;
- клеї застосовують на основі ПВА, на силікатній (розчин силікату натрію) або крохмальній основі.

Основні фізико-механічні характеристики, що визначають якість гофрованого картону наведено в табл. 2. Залежно від того, що гофрований картон застосовується також для транспортної тари, особливої уваги вимагає дотримання значень його характеристик площинної і торцевої міцності та амортизаційні властивості при різних впливах зовнішнього середовища та сторонніх сил.

Гофрований картон відносимо до анізотропних матеріалів, що мають показники міцності вздовж (MD) і поперек (CD) гофрів

Таблиця 1

Профілі гофрів гофрованого картону

\begin{tabular}{|c|c|c|c|c|c|}
\hline $\begin{array}{l}\text { Тип } \\
\text { гофру }\end{array}$ & $\begin{array}{c}\text { Структура гофрованого } \\
\text { картону }\end{array}$ & $\begin{array}{c}\text { Наймену- } \\
\text { вання } \\
\text { гофру }\end{array}$ & $\begin{array}{c}\text { Висота } \\
\text { гофру, мм }\end{array}$ & $\begin{array}{c}\text { Крок гофру, } \\
\text { мм }\end{array}$ & $\begin{array}{c}\text { Кількість } \\
\text { хвиль } \\
\text { на } 1 \text { пог. м }\end{array}$ \\
\hline A & V & крупний & $4,4-5,5$ & $8-9,5$ & 108-118 \\
\hline B & wh & мілкий & $2,2-3,2$ & $4,5-6,4$ & $154-164$ \\
\hline C & w & середній & $3,2-4,4$ & $6,5-8,0$ & $127-137$ \\
\hline $\mathrm{E}$ & wnownen & мікро & $1,1-1,6$ & $3,2-3,6$ & 295-315 \\
\hline $\mathrm{F}$ & 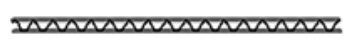 & & 0,75 & 2,4 & $413-415$ \\
\hline G & wans & & 0,55 & 1,8 & $553-555$ \\
\hline $\mathrm{N}$ & ransensens & & 0,50 & $<1,8$ & $>565$ \\
\hline$A+B$ & vusurusur & - & - & - & - \\
\hline$C+B$ & ॠhesh & - & - & - & - \\
\hline$E+B$ & एतs & - & - & - & - \\
\hline
\end{tabular}




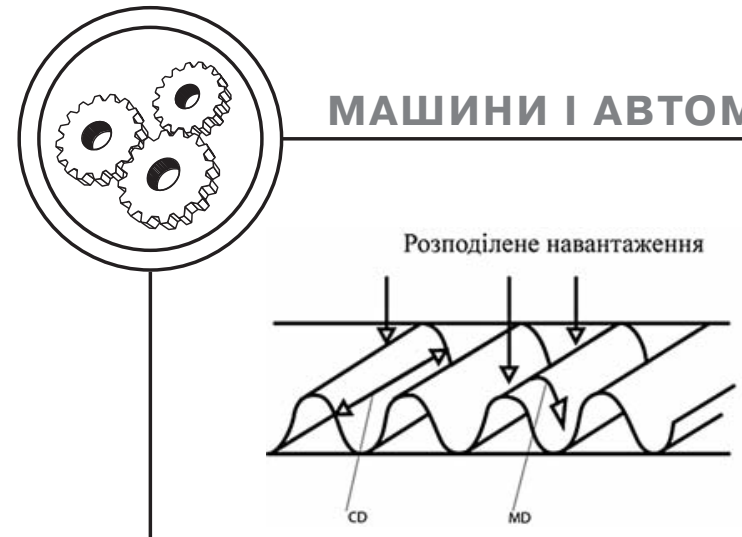

a

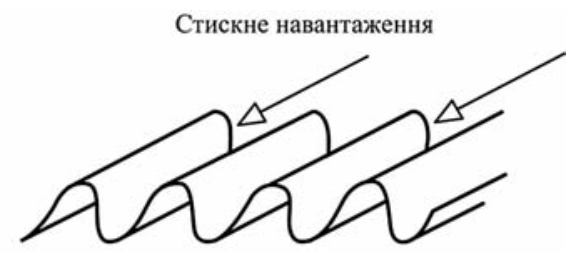

б

Рис. 3. Площинний та вертикальний стиск аркуша гофрованого картону: a - перпендикулярна дія навантаження; б - дія навантаження вздовж гофрів

(рис. 3). Тому при задруковуванні гофрованого картону уздовж машинного напряму або перпендикулярно до нього, технологіч- ні навантаження мають різні значення $[7,8]$. Під дією навантаження, що перпендикулярно до напрямку гофрів, структура гоф-

Таблиця 2

Характеристики гофрованого картону та методи випробувань

\begin{tabular}{|c|c|c|c|}
\hline Характеристика & $\begin{array}{c}\text { Розрахункова } \\
\text { формула }\end{array}$ & Схема випробувань & $\begin{array}{c}\text { Методика вимірю- } \\
\text { вань та нормативна } \\
\text { документація }\end{array}$ \\
\hline $\begin{array}{l}\text { Опір торцевому } \\
\text { тиску вздовж } \\
\text { гофрів, кН/м }\end{array}$ & $\begin{array}{l}\mathrm{q}_{\mathrm{cт}}=\frac{\mathrm{F}}{\mathrm{l}}, \\
\text { де } \mathrm{F}-\text { руйнівне } \\
\text { зусилля, } \mathrm{H} ; \mathrm{I}- \\
\text { довжина взірця, м }\end{array}$ & & $\begin{array}{l}\text { Визначається руй- } \\
\text { нівне зусилля при } \\
\text { стиску взірця, по- } \\
\text { ставленого на то- } \\
\text { рець }\end{array}$ \\
\hline $\begin{array}{l}\text { Абсолютний } \\
\text { опір продавлю- } \\
\text { ванню, Р, кПа }\end{array}$ & $\begin{array}{l}\text { Визначення тиску, } \\
\text { при якому відбу- } \\
\text { вається руйну- } \\
\text { вання взірця }\end{array}$ & 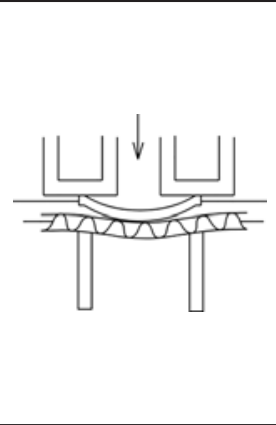 & $\begin{array}{l}\text { Фіксований, по- } \\
\text { вільно зростаючий } \\
\text { тиск на приладі } \\
\text { гідравлічного ти- } \\
\text { пу, з резиновою } \\
\text { діафрагмою на } \\
\text { взірець, затисну- } \\
\text { тий між двома } \\
\text { кільцями до його } \\
\text { руйнування. } \\
\text { ГОСТ 13525.8-86 }\end{array}$ \\
\hline $\begin{array}{l}\text { Опір площин- } \\
\text { ному стиску } \\
\text { взірця ГК, FCT, } \\
\sigma_{\mathrm{cт}}, \mathrm{H} / \mathrm{cm}^{2}\end{array}$ & $\begin{array}{l}\sigma_{\text {ст }}=\frac{\mathrm{F}}{\mathrm{S}}, \\
\text { де } \mathrm{F}-\text { руйнівне } \\
\text { зусилля, } \mathrm{H} ; \mathrm{S}- \\
\text { площа взірця, мм²2 }\end{array}$ & & $\begin{array}{l}\text { Взірець встанов- } \\
\text { люється між дво- } \\
\text { ма плитами, одна } \\
\text { з яких рухається } \\
\text { вниз до руйнуван- } \\
\text { ня взірця. } \\
\text { ГОСт 20681-75 }\end{array}$ \\
\hline
\end{tabular}


рованого картону діє як амортизуючий матеріал (рис. 3, а). Якщо навантаження діє вздовж гофрів, гофрований картон працює як жорсткий матеріал, що майже не деформується (рис. 3, б). Ці особливості картону використовують при конструюванні тари для транспортування, яка повинна задовольняти вимоги цілісності паковання [9], а саме: витримувати торцеве стиснення у вертикальному напрямі - при штабелюванні, а вздовж і поперек бокових стінок - при транспортуванні. Всі плоскі шари лайнери - фіксують положення гофрів, функціонують на спротив до стиснення, розрив, а також чинять опір продавлюванню. В таких випадках співвідношення MD/CD складає 1,0...1,4.
До експлуатаційних властивостей гофрованого картону відносимо наступні властивості, що залежать від фізико-механічних характеристик:

- можливість отримання надійного, а саме жорсткого і міцного паковання;

- придатність до обробки, а саме: друкування, лакування, склеювання тощо;

- сенсорні і бар'єрні властивості паковання.

Аналіз і дослідження впливу фізико-механічних властивостей гофрованого картону дозволили систематизувати характеристики на придатність до його задруковування (табл. 3).

Величина опору площинному стиску гофрованого картону досить суттєво впливає на техно-

Таблиця 3

Вплив характеристик гофрованого картону на придатність до задруковування

\begin{tabular}{|c|c|c|}
\hline \multirow{2}{*}{ Експлуатаційні властивості } & \multicolumn{2}{|c|}{ Характеристики } \\
\hline & Багатошаровий картон & Гофрокартон \\
\hline \multirow{9}{*}{$\begin{array}{l}\text { Придатність до друку- } \\
\text { вання і лакування }\end{array}$} & $\begin{array}{l}\text { Білизна покривного } \\
\text { і першого шару }\end{array}$ & $\begin{array}{l}\text { Колір зовнішнього } \\
\text { лайнера }\end{array}$ \\
\hline & Глянець & $\begin{array}{l}\text { Шорсткість } \\
\text { зовнішнього лайнера }\end{array}$ \\
\hline & Гладкість & Опір розшаруванню \\
\hline & Опір розшаруванню & $\begin{array}{l}\text { Поверхневе всотування } \\
\text { зовнішнього лайнера }\end{array}$ \\
\hline & $\begin{array}{l}\text { Стійкість до вищипу- } \\
\text { вання }\end{array}$ & $\begin{array}{l}\text { Кількість хвиль гофрів } \\
\text { на м² }\end{array}$ \\
\hline & Поверхневе всотування & Різнотовщинність \\
\hline & Структура і склад & $\begin{array}{l}\text { Опір площинному } \\
\text { стиску }\end{array}$ \\
\hline & Міжшарова міцність & \\
\hline & Різнотовщинність & \\
\hline
\end{tabular}


логічний тиск при друці $[10,11]$, оскільки при збільшенні тиску виникає такий дефект, як ефект «пральної дошки». Даний показник суттєво залежить від кількості хвиль на 1 пог. м (табл. 1) та конструкції гофрованого картону [12].

Було проведено експериментальні дослідження опору площинному стиску гофрованого картону, в якому було враховано його вид і типи гофрів. Було визначено, що абсолютні деформації при значеннях друкарського тиску 0,05...0,3 МПа знаходяться у діапазоні 0,08...0,2 мм. Аналіз літератури показав [13, 14], що на сьогодні немає чітких рекомендацій щодо питомого тиску при друці на гофрованому картоні залежно від його структури й фізико-механічних властивостей.

Проведений аналіз експлуатаційних властивостей гофрованого картону показав, що для задруковування заготовок на флек- сографічних аркушевих машинах повинні бути враховані наступні фактори:

- характеристики та структура зовнішнього лайнеру: поверхневе всотування, шорсткість, колір;

- структура (тип) гофрованого картону і анізотропність його фізико-механічних характеристик, особливо - опір площинному стиску;

- різнотовщинність заготовки по всій площині, що задруковується.

При дослідженні проходження заготовок через транспортувальну систему було визначено, що досить великий вплив на плавність має поверхня направляючих.

Механізми вирівнювання разом із направляючими забезпечують стабільне прямокутне положення аркушів по відношенню до форми перед подачею їх в друкарську секцію. Це пов'язано з необхідністю точного співвідношення і сталості розмірів полів на відбитках, а також точного

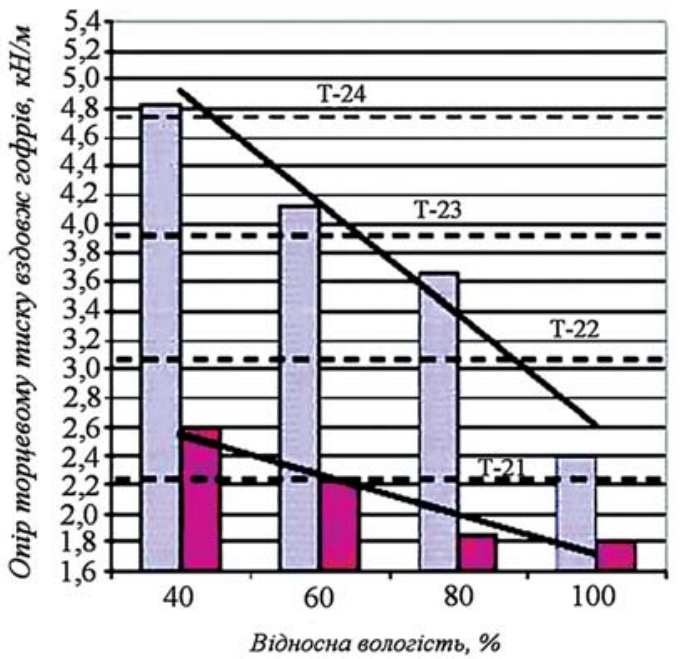

Рис. 4. Вплив вологості на міцність гофрованого картону 


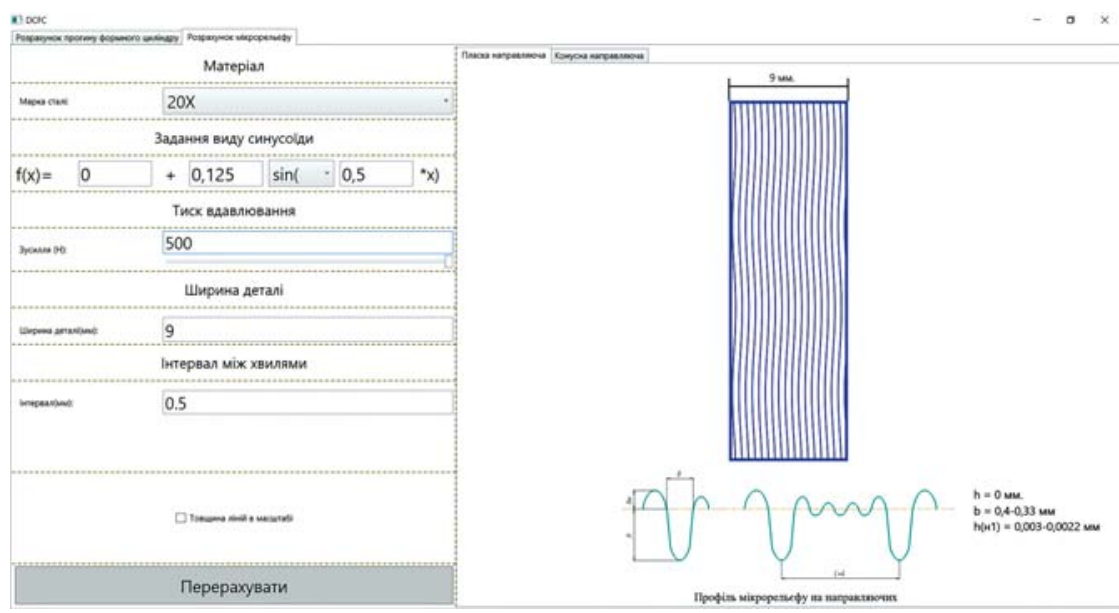

Рис. 5. Програмна утиліта розрахунку типу синусоїди

накладання фарб при друкуванні в кілька прогонів. Було проведено експеримент і запропоновано утворення мікронаправляючих на пласких поверхнях транспортуючої системи аркушевої флексографічної машини методом поверхневого пластичного деформування. Це значно покращило плавність руху і позиціювання гофрокартону при його переміщенні по направляючим флексографічного обладнання і, як наслідок, якісне відтворення необхідної інформації на поверхні задрукованої продукції.

Для даної задачі був створений програмний комплекс, який аналітично прораховує тип синусоїди та візуалізує майбутній результат за введеними значеннями (рис. 5).

\section{Висновки}

Завдяки проведеному дослідженню було визначено наступні експлуатаційні властивості гофрованого картону, що впливають на його придатність до задруковування:
- оптичні характеристики, що визначаються такими показниками, як білизна і ступінь глянцю зовнішніх шарів лайнерів і їх здатністю до поверхневого всотування;

- опір розшаруванню, що визначається через придатність гофрованого картону на його проводку (транспортування) у флексографічних аркушевих машинах і на швидкість друку.

- опір площинному стиску має значний вплив на технологічні навантаження і якість друку на заготовках гофрованого картону, який визначається відношенням руйнівної величини тиску до площі друкарського контакту;

- вологість, яка в свою чергу суттєво впливає на міцність і жорсткість гофрованого картону. Лицьовий шар картону має таку поверхню, яка добре вбирає вологу і фарбу, а це призводить до втрати міцнісних характеристик виробу, особливо в машинному напрямку (рис. 4), що вимагає коригувати величину тиску при друці, оскільки застосовуються рідкі водорозчинні фарби; 
- точність позиціювання заготовок гофрокартону на направляючих збільшилась на 33...37 \%;

- дефекти при друці, а саме несуміщення фарб зменшилось на $14 \ldots 18 \%$;
- плавність проходження заготовок зросла на $20 \%$;

- збільшення швидкості друку за рахунок зменшення похибок позиціювання можливе на $5 . . .10 \%$.

\section{Список використаної літератури}

1. ГОСТ 15467-79. Управление качеством продукции. Основные показатели. Термины и определения.

2. ГОСТ 4353-85. Система показателей качества продукции. Оборудование полиграфическое. Номенклатура показателей.

3. ГОСТ 2.601-2006. Единая система конструкторской документации. Эксплуатационные документы.

4. ГОСТ 27.002-89. Надежность в технике. Термины и определения.

5. Киппхан Г. Энциклопедия по печатным средствам информации / Г. Киппхан. М.: МГУП, 2003. 1280 с.

6. Сорокин Б. А. Флексографская печать / Б. А. Сорокин, О. В. Здан. М.: МГАП «Мир книги», 1996. 192 с.

7. Ярема С. М. Флексографія. Обладнання. Технологія: навчальний посібник / С. М. Ярема. К.: Либідь, 1998. 312 с.

8. Баранкевич А. Как производится гофрократон / А. Баранкевич // Гофро индустрия. 2004. № 2 .

9. Мартинюк Ф. У центрі уваги - паковання з гофрованого картону / Ф. Мартинюк // Друкарство. 2005. № 5. С. 11-15.

10. Звіт World Packaging Organisation. 2018.

11. Ефремов Н. Печать на гофрокартоне / Н. Ефремов // Гофро индустрия. 2004. № 3(3). С. 18-24.

12. Роджерс Э. Флексопечать и гофрокартон: навстречу друг другу / Э. Роджерс // Флексодрук РЕВЮ. 2001. № 2. С. 40.

13. Кондратьєв С. Аналіз фарбових систем сучасних флексографічних машин / С. Кондратьєв // Друкарство. 2004. № 2. С. 59-61.

14. Дуб Я. І. Деформація друкарського елемента фотополімерної форми / Я. І. Дуб, Г. В. Огірко, М. Ф. Ясінський // Сб. «Поліграфія і видавнича справа». 1986. Вип. 4. С. 49.

\section{References}

1. GOST 15467-79. Upravlenie kachestvom produktsii. Osnovnye pokazateli. Terminy i opredeleniya [GOST 15467-79. Product Quality Management. Main Characteristics. Terms and Definitions] [in Russian].

2. GOST 4353-85. Sistema pokazateley kachestva produktsii. Oborudovanie poligraficheskoe. Nomenklatura pokazateley [GOST 4353-85. The System of Indicators of Product Quality. Polygraphic Equipment. Nomenclature of Indicators] [in Russian].

3. GOST 2.601-2006. Edinaya sistema konstruktorskoy dokumentatsii. Ekspluatatsionnye dokumenty [GOST 2.601-2006. Unified System for Design Documentation. Operational Documents] [in Russian].

4. GOST 27.002-89. Nadezhnost'v tekhnike. Terminy i opredeleniya [GOST 27.002-89. Reliability in Technology. Terms and Definitions] [in Russian].

5. Kipkhan, G. (2003). Entsiklopediya po pechatnym sredstvam informatsii [Encyclopedia of Print Media]. Moscow: MGUP, 1280 p. [in Russian]. 
6. Sorokin, B. A. \& Zdan, O. V. (1996). Fleksografskaya pechat' [Flexo Printing]. Moscow: MGAP 'Mir knigi', 192 p. [in Russian].

7. Yarema, S. M. (1998). Fleksohrafiia. Obladnannia. Tekhnolohiia [Flexography. Equipment. Technology]. Kyiv: Lybid, 312 p. [in Ukrainian].

8. Barankevich, A. (2004). Kak proizvoditsya gofrokraton [How is Corrugated Board Made]. Journal of Gofro industriya, 2 [in Russian].

9. Martyniuk, F. (2005). U tsentri uvahy - pakovannia z hofrovanoho kartonu [The Focus is on Corrugated Cardboard Packaging]. Journal of Drukarstvo, 5, 11-15 [in Ukrainian].

10. (2018). Zvit World Packaging Organisation [Report of World Packaging Organisation] [in Ukrainian].

11. Efremov, N. (2004). Pechat' na gofrokartone [Printing on Corrugated Board]. Journal of Gofro industriya, 3(3), 18-24 [in Russian].

12. Rodzhers, E. (2001). Fleksopechat' i gofrokarton: navstrechu drug drugu [Flexo Printing and Corrugated Board: Towards Each Other]. Journal of Fleksodruk REVYu, 2, 40 [in Russian].

13. Kondratiev, S. (2004). Analiz farbovykh system suchasnykh fleksohrafichnykh mashyn [Analysis of Ink Systems of Modern Flexographic Machines]. Journal of Drukarstvo, 2, 59-61 [in Ukrainian].

14. Dub, Ya. I. \& Ohirko, H. V. \& Yasinskyi, M. F. (1986). Deformatsiia drukarskoho elementa fotopolimernoi formy [Deformation of the Printing Element of the Photopolymer Form]. Journal of Polihrafiia i vydavnycha sprava, 4, 49 [in Ukrainian].

There are shows a diagram of technical and operational properties of corrugated board. This paper considers the following functional indicators of the first group, related primarily to the requirements for the rigidity of the printing apparatus. In addition, the systematization of the factors influencing $t$ he functional characteristics and parameters of the printing apparatus on the typical phenomena that occur in the printing process.

\title{
Keywords: flex print; print unit; corrugated board;
} liner; fluting; pressure.

\author{
Рецензент - О. О. Палюх, канд. техн. наук, \\ доц., КПІ ім. Ігоря Сікорського
}

Надійшла до редакції 24.10.20 